\title{
State-of-the-Art Production Chains for Peas, Beans and Chickpeas-Valorization of Agro-Industrial Residues and Applications of Derived Extracts
}

\author{
Annalisa Tassoni ${ }^{1, *(\mathbb{D}}$, Tullia Tedeschi ${ }^{2}$, Chiara Zurlini ${ }^{3}{ }^{\mathbb{D}}$, Ilaria Maria Cigognini ${ }^{3}$, \\ Janos-Istvan Petrusan ${ }^{4,+}$, Óscar Rodríguez ${ }^{5}{ }^{\oplus}$, Simona Neri ${ }^{5}$, Annamaria Celli ${ }^{6}$, Laura Sisti ${ }^{6}{ }^{\circ}$, \\ Patrizia Cinelli ${ }^{7,8}\left(\mathbb{D}\right.$, Francesca Signori ${ }^{7,8}$, Georgios Tsatsos ${ }^{9}$, Marika Bondi ${ }^{10}$, \\ Stefanie Verstringe ${ }^{11}$, Geert Bruggerman ${ }^{11}$ and Philippe F. X. Corvini ${ }^{12}$ \\ 1 Department of Biological Geological and Environmental Sciences, University of Bologna, Via Irnerio 42, \\ 40126 Bologna, Italy \\ 2 Department of Food and Drug, University of Parma, Parco Area delle Scienze 27/A, 43124 Parma, Italy; \\ tullia.tedeschi@unipr.it \\ 3 Experimental Station for Food Preservation Industry, Viale F. Tanara, 31/A, 43121 Parma, Italy; \\ chiara.zurlini@ssica.it (C.Z.); ilaria.cigognini.cococo@ssica.it (I.M.C.) \\ 4 Institut für Getreideverarbeitung GmbH, Arthur-Scheunert Allee 40/41, 14558 Nuthetal, Germany; \\ J.Petrusan@dil-ev.de \\ 5 IRIS Technology Group, Avda. C. F. Gauss 11, 08860 Castelldefels, Spain; orodriguez@iris.cat (O.R.); \\ sneri@iris.cat (S.N.) \\ 6 Department of Civil, Chemical, Environmental and Materials Engineering, University of Bologna, Via \\ Terracini 28, 40138 Bologna, Italy; annamaria.celli@unibo.it (A.C.); laura.sisti@unibo.it (L.S.) \\ 7 Department of Civil and Industrial Engineering, University of Pisa, Largo Lucio Lazzarino 2, \\ 56126 Pisa, Italy; patrizia.cinelli@unipi.it (P.C.); francesca.signori@unipi.it (F.S.) \\ 8 National Interuniversity Consortium of Materials Science and Technology, Via G. Giusti 9, \\ 50121 Firenze, Italy \\ 9 Cosmetic Tsatsos Georgios, Ioannou Metaxa 56, 19441 Koropi, Greece; g.tsatsos@cosmetic.com.gr \\ 10 Conserve Italia Scarl, Via Paolo Poggi 11, 40068 San Lazzaro di Savena (BO), Italy; mbondi@ccci.it \\ 11 Nutritional Solutions Division, Nutrition Sciences NV, Booiebos 5, 9031 Drongen, Belgium; \\ stefanie.verstringe@nusciencegroup.com (S.V.); geert.bruggeman@nusciencegroup.com (G.B.) \\ 12 Institute for Ecopreneurship, School of Life Sciences, Fachhochschule Nordwestschweiz, Hofackerstrasse 30, \\ CH-4132 Muttenz, Switzerland; philippe.corvini@fhnw.ch \\ * Correspondence: annalisa.tassoni2@unibo.it; Tel.: +30-051-209-1280 \\ + Present address: German Institute of Food Technologies, Prof.-von-Klitzing Strasse 7, D-49610 \\ Quakenbrück, Germany.
}

Received: 3 February 2020; Accepted: 17 March 2020; Published: 18 March 2020

check for updates

\begin{abstract}
The world is confronted with the depletion of natural resources due to their unsustainable use and the increasing size of populations. In this context, the efficient use of by-products, residues and wastes generated from agro-industrial and food processing opens the perspective for a wide range of benefits. In particular, legume residues are produced yearly in very large amounts and may represent an interesting source of plant proteins that contribute to satisfying the steadily increasing global protein demand. Innovative biorefinery extraction cascades may also enable the recovery of further bioactive molecules and fibers from these insufficiently tapped biomass streams. This review article gives a summary of the potential for the valorization of legume residual streams resulting from agro-industrial processing and more particularly for pea, green bean and chickpea by-products/wastes. Valuable information on the annual production volumes, geographical origin and state-of-the-art technologies for the extraction of proteins, fibers and other bioactive molecules from this source of biomass, is exhaustively listed and discussed. Finally, promising applications, already using the recovered fractions from pea, bean and chickpea residues for the formulation of feed, food, cosmetic and packaging products, are listed and discussed.
\end{abstract}


Keywords: agro-industrial by-products; biowaste; biomass; fibers; legumes; plant proteins

\section{Introduction}

In recent years, the management of agro-industrial and food processing by-products, residual matter and waste has arisen considerable interest from farmers, food producers, retailers and consumers. The food and food ingredient industrial production is associated with the generation of large, and sometimes unavoidable, by-products and waste streams; about $38 \%$ of the residues wastes are generated during food processing [1]. According to the Food and Agriculture Organization of the United Nations (FAO), about 1.3 billion tons of food is lost or wasted per year, along the whole production chain starting at the production stage and ending at the consumer level. Among all food commodities, fruit and vegetables (such as legumes) are the largest food waste contributor representing $44 \%$ of the global food waste, roots and tubers contributing by $20 \%$ and cereal by $19 \%$ [2].

Agro-industrial and food processing by-products and waste are not only a sustainability problem with respect to environmental deterioration, but also an economic problem since they have a direct impact on production profitability. To improve the sustainability of agro-food production, it is essential to have a comprehensive understanding of the various sources of residual biomass generated throughout the supply and production chains from the farm to the consumer's table.

Several studies have focused on the quantitative estimation of residual biomass streams for the recovery of raw materials, chemicals and energy [3-6]. In addition, the European Waste Catalogue (EWC) [7], provided a standardized description of different by-products/wastes which were identified and classified into several categories according to their production, transportation, handling or treatment.

In general, agro-food by-products and wastes are considered to have little value and are often employed as useful substrates for bioenergy/biofuel production, such as a fermentation substrate for the production of biogas and bioethanol [8-10], or as an animal feed, since they meet the minimum quality criteria [11]. Nonetheless, in recent years, agro-food residues valorization practices have attracted significant attention with the aim of finding more sustainable managing systems. In particular, food by-products/wastes represent largely under-exploited residues from which a variety of chemicals can be derived. In fact, these streams could be used more efficiently by developing industrial biorefinery processes aimed at the energy-efficient recovery of high-value components finding application in several industrial markets, as well as at the concomitant production of fertilizers and/or energy [12-16] (Figure 1).
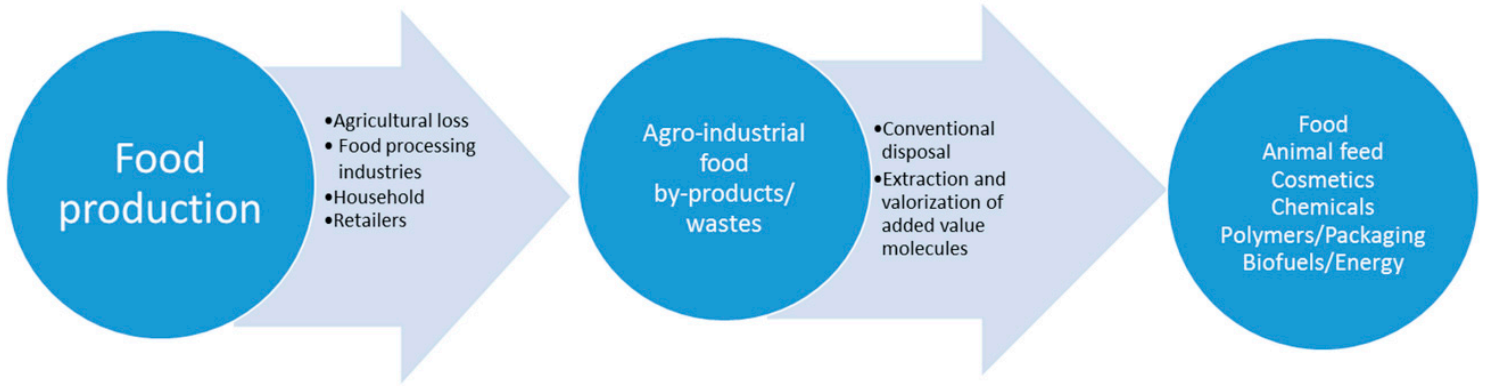

Figure 1. Valorization routes of residues generated by the agro-industrial food processing pipeline.

The recovery of valuable compounds from agro-food waste was increasingly investigated and different approaches were considered following the Five-Stage Universal Recovery Process [17]. During this process, in order to effectively separate the targeted compounds from the waste matrix, a progressive separation procedure from the macroscopic to macromolecular, and then to the micromolecular level is applied. Generally, five distinct stages were identified: macroscopic pre-treatment; macro- and 
micro-molecules separation; extraction; isolation and purification; product formation. Each step can be carried out with different conventional or emerging technologies and the main advantage of this strategy is that it can be applied for simultaneous recovery of several ingredients in different streams $[17,18]$.

Specifically, legume residues are rich in proteins and peptides as well as fibers that can be extracted and further valorized in several industrial fields [11,19-22], making culture practices more profitable and reducing human dependency on animal products. In addition, they can also be a potential source of many other bioactive molecules (e.g., phenols, carotenoids, phytosterols and fibers) that have been proven to exert a beneficial impact on human health $[23,24]$.

This review article presents an overview of by-product/waste generation during legume agro-industrial processing. These crops, and in particular peas, chickpeas and beans, represent an extremely interesting case due to their steadily increasing production and a high annual turnover in the European Union and worldwide given the rising demand of vegetarian/vegan consumers. Mapping and discussion of the main opportunities related to the extraction and fraction valorization technologies mainly of proteins, fibers and other bioactive molecules (e.g., polyphenols and carotenoids) from these biomass streams are described. Current applications and challenges related to the recovered molecules in the feed, food, cosmetic and packaging sectors are also reported.

\section{World and European Legume Production}

Worldwide and European total legume production has been increasing in the last ten years by about $34 \%$ and $44 \%$ respectively, with soybeans, beans, peas and chickpeas being the most abundant crops in terms of total production in 2017 [25] (Table 1).

Table 1. European production amount (in million tons, MT) of different legumes. Data from the FAOSTAT food and agriculture database and related to 2017 [25].

\begin{tabular}{ccc}
\hline Legume Type & World (MT) & Europe (MT) \\
\hline Beans (dry) & 31.41 & 0.62 \\
\hline Beans (green) & 24.22 & 0.77 \\
\hline Broad Beans (dry) & 4.84 & 0.97 \\
\hline Caw Peas & 7.41 & 0.002 \\
\hline Chickpeas & 14.78 & 0.13 \\
\hline Lentils & 7.59 & 0.07 \\
\hline Lupins & 1.61 & 0.25 \\
\hline Peas (dry) & 16.21 & 2.60 \\
\hline Peas (green) & 20.70 & 0.93 \\
\hline Soybeans & 35.26 & 2.67
\end{tabular}

Overall, the major 2017 legume producers in Europe are France, the UK, Italy, Germany and Spain [25]. Given their continental cold climate, France, Germany and the UK specialized in the cultivation of more productive legume crops (soybean, peas and broad beans), while other countries, such as Italy and Spain, cultivate large areas of a heterogeneous group of leguminous plants more adapted to Mediterranean environments.

The pea is one of the most important nutritional crops grown across the World and Europe as it is rich in protein content (18\%-30\% [26]) and can be grown in frost-hardy and cold climates. In general, two types of peas are commonly commercialized: green peas (Pisum sativum L.) marketed as fresh or canned, and yellow peas (Pisum sativum L. var. macrocarpon) commonly called dry peas as they are marketed in dried form, with yellow peas dominating the global production. According to FAOSTAT 
food and agriculture database [25], the World production of green peas amounted to 20.70 million tons (MT) in 2017, while the global production of dry peas was estimated at 16.21 MT (Table 1).

In 2017, China was, by far, the country with the largest production of green peas (61\% of global production) followed by India (26\%) and the USA (1.2\%) (Figure 2). Therefore, Asia is the largest green pea producer, covering about $88.3 \%$ of global production, while Europe and America, only account for $5.5 \%$ and $3.1 \%$, respectively (Figure 3A). In Europe, the major producers are France, Spain and the UK.

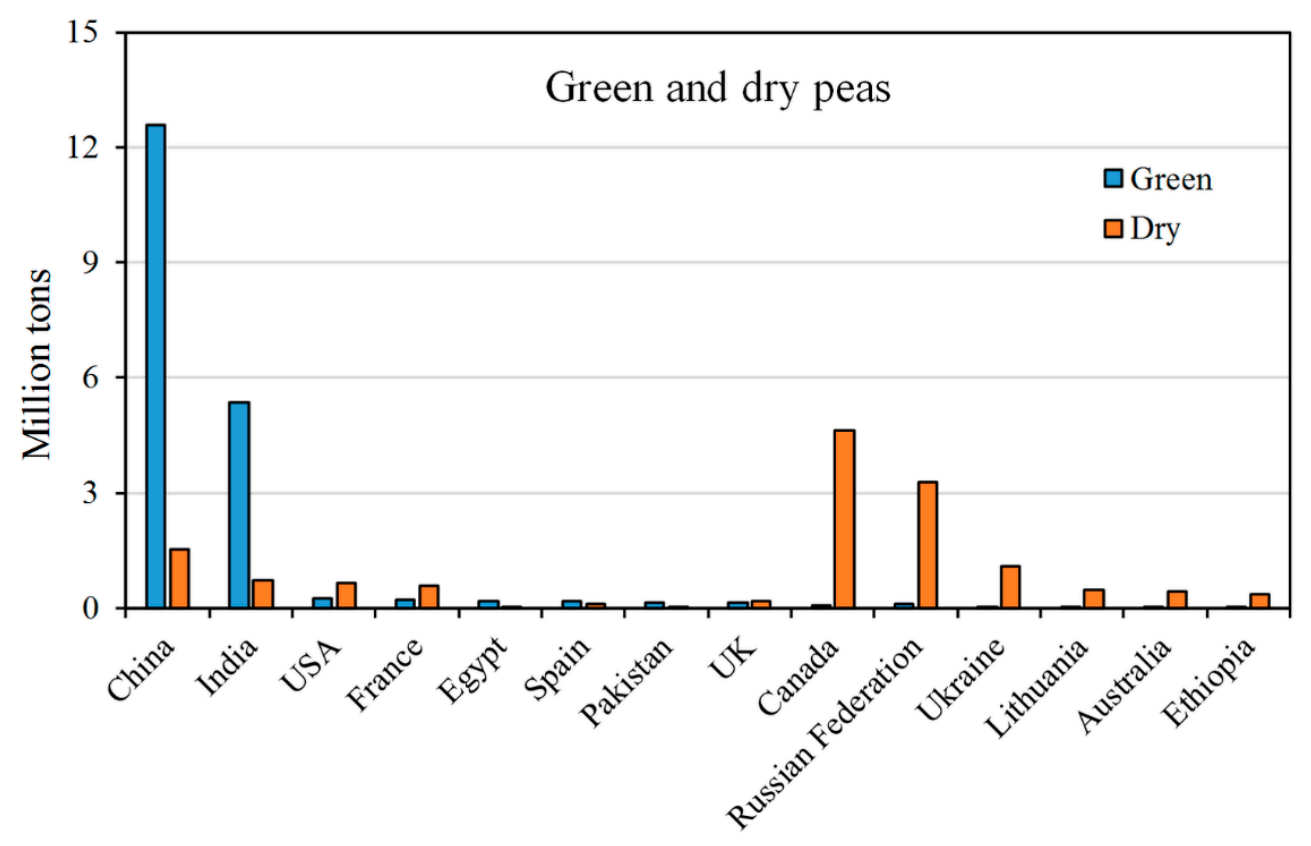

Figure 2. The top world producers (million tons) of green and dry peas in 2017. Data from the FAOSTAT database [25].

A Production share of green peas by continent

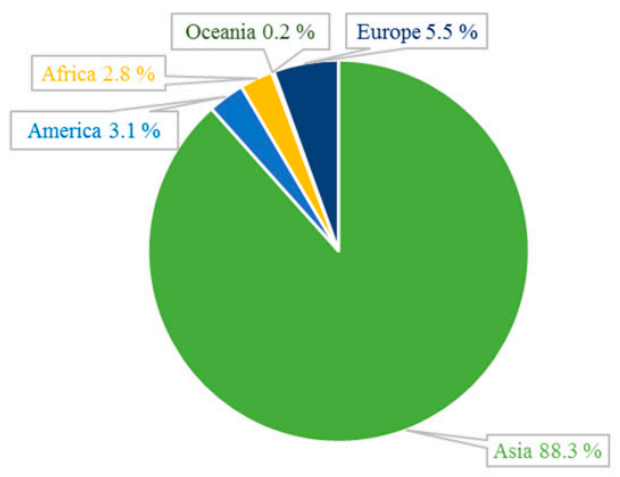

B Production share of dry peas by continent

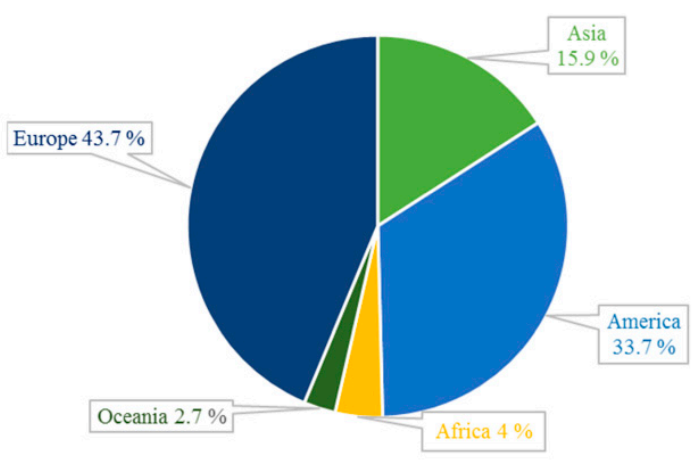

Figure 3. Production share of green and dry peas by region. Data from the FAOSTAT database (year 2017) [25].

As regards dry yellow peas, in 2017 Canada was the largest producer (4.63 MT), followed by the Russian Federation (3.29 MT) and China (1.52 MT) (Figure 2).

Different from green peas, dry yellow peas are mainly produced in Europe (43.7\%), North and South America (33.7\%) and Asia (15.9\%) (Figure 3B).

The common bean (Phaseolus vulgaris L.) is usually known under different names (French bean, kidney bean, snap bean, runner bean or string bean) and is grown and commercialized as fresh seed (green bean) or dry seed. The common bean grows well in medium rainfall areas and it is not suited to the humid and wet tropics. 
The total green and dry bean production reached, worldwide in 2017, a total amount of approximately 55.6 MT (Table 1). The major producer of green beans was China, followed by Indonesia and India, while dry beans were mostly produced by India, Myanmar and Brazil (Figure 4). Europe mostly commercializes green beans (0.77 MT in 2017, Table 1) with Spain and Italy being the countries mainly involved (Figure 4).

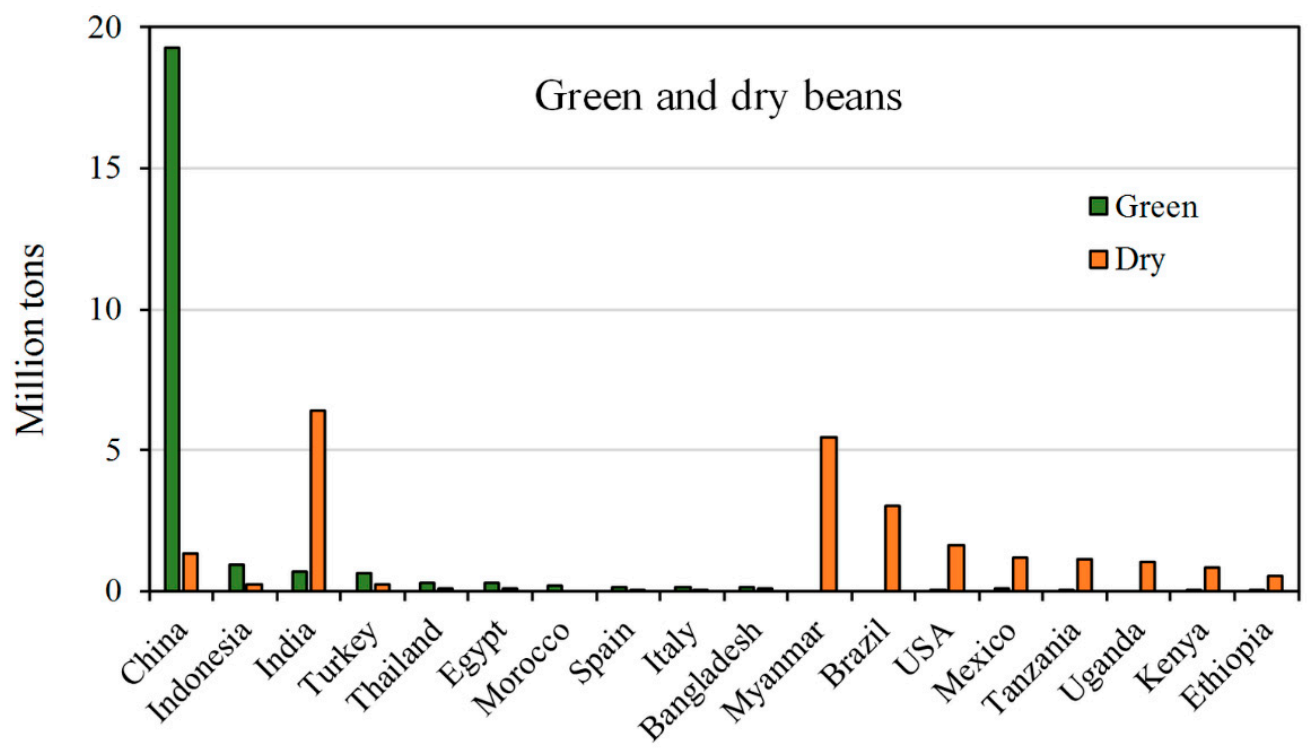

Figure 4. Top world producers (million tons) of green and dry beans in 2017. Data from the FAOSTAT database [25].

Consequently, Asia is the continent with the highest production of both green and dry beans with $91.9 \%$ and $49.3 \%$ of total production share, respectively. Particularly for dry beans, America and Africa also showed a relevant share in 2017 (25.2\% and $21.8 \%$, respectively [25]).

The chickpea is one of the oldest legumes and was domesticated around $3500 \mathrm{BC}$. The two main cultivated varieties of chickpeas (Cicer arientinum L.) are the large, light-seeded Kabuli type, also called garbanzo beans, and the small, dark-seeded Desi type.

The smooth Kabuli chickpeas are mostly farmed in European and African countries surrounding the Mediterranean Sea and are mostly marketed for domestic use. The Desi chickpeas have a rough appearance and a variety of colors, especially in Asian and African countries where they are also sold as milled flour [27].

Given its high protein content (almost $40 \%$ of seed weight), the chickpea is playing a leading role in covering the deficit in proteins of daily food ratios in Asian (especially Indian) and African sub-Saharan populations.

Globally, India is the largest chickpea producer, accounting alone for about $67 \%$ of the total production in 2017 (Figure 5), followed by Australia (14\% of share). Europe holds only 4\% of the total chickpea production, with Spain (0.06 MT) and Italy (0.03 MT) as major 2017 producers [25]. Worldwide, the chickpea ranks fourth among legume crops, with a production of 14.78 MT (Table 1). 


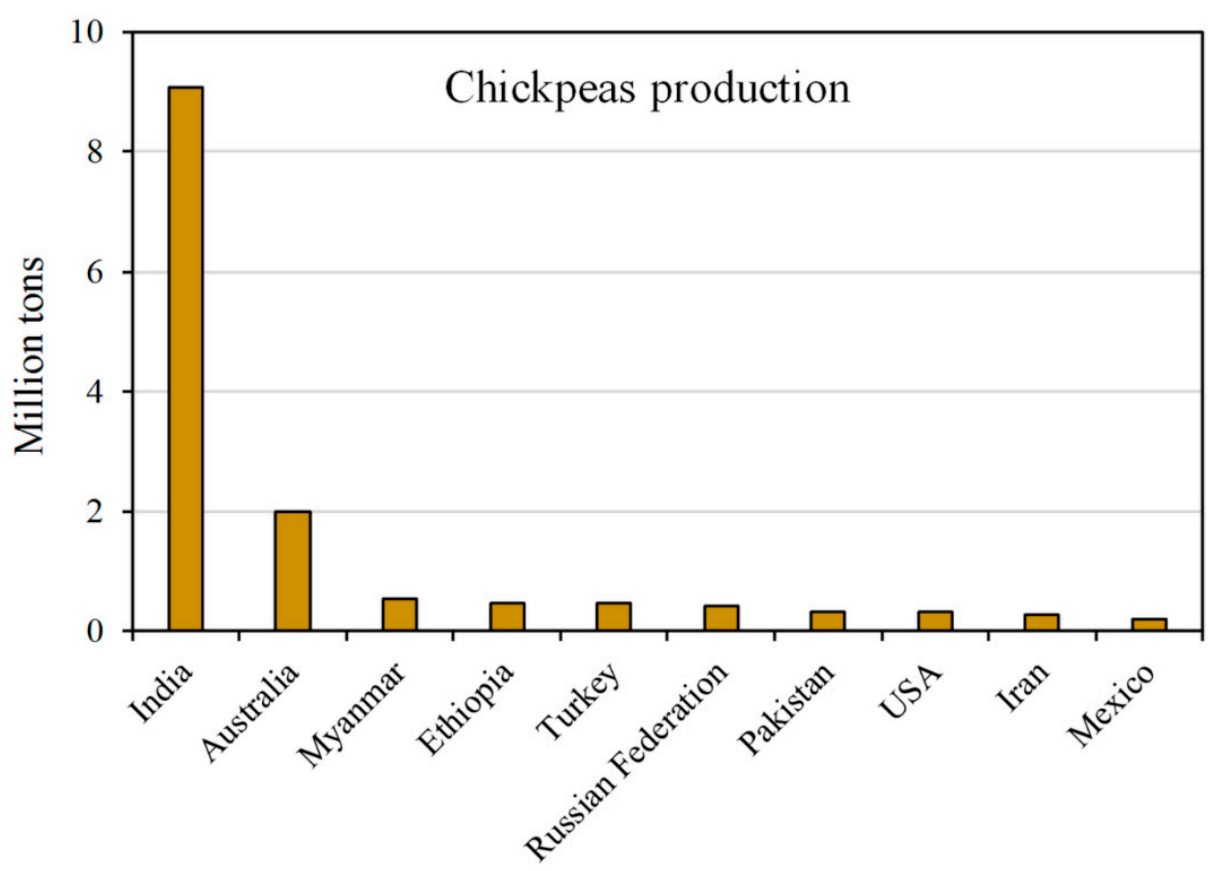

Figure 5. Top world producers (million tons) of chickpeas in 2017. Data from the FAOSTAT database [25].

Taken together, the annual combined production of peas, beans and chickpeas accounts for about $65 \%$ of global legume production [28] (Table 1).

World and European long-term market trends indicate an increasing demand for high-quality plant proteins. In this view, the growing use of legume proteins seems unavoidable, in particular for peas, beans and chickpeas, due to consumer preference for soy-free products. Therefore, a strong future increment of the world production of these legume crops is foreseen $[29,30]$.

\section{Legume By-Products/Wastes Generation During the Processing Chain}

Throughout the legume agro-industrial processing pipeline, large amounts of residues, by-products and wastes are generated in particular during harvesting and field processing, when damaged legumes are discarded. In addition, pods and other seed residues are left over from the cleaning and splitting operations during industrial processing.

Pea, bean and chickpea processing (canning, freezing and/or drying) generates a mixture of leaves, stems and empty pods resulting from the fresh legumes processing steps.

According to estimates from the company Conserve Italia Scarl. (Italy), one of the EU's largest legume producers and processors, the quantity of residues originating from the legume agro-industrial pipeline ranges from $5 \%$ to $25 \%$ of the crop initially harvested.

As an example, the flow-chart related to the industrial process of preserved products starting from fresh legumes is shown in Figure 6. In red are the steps corresponding to by-products/wastes production. 


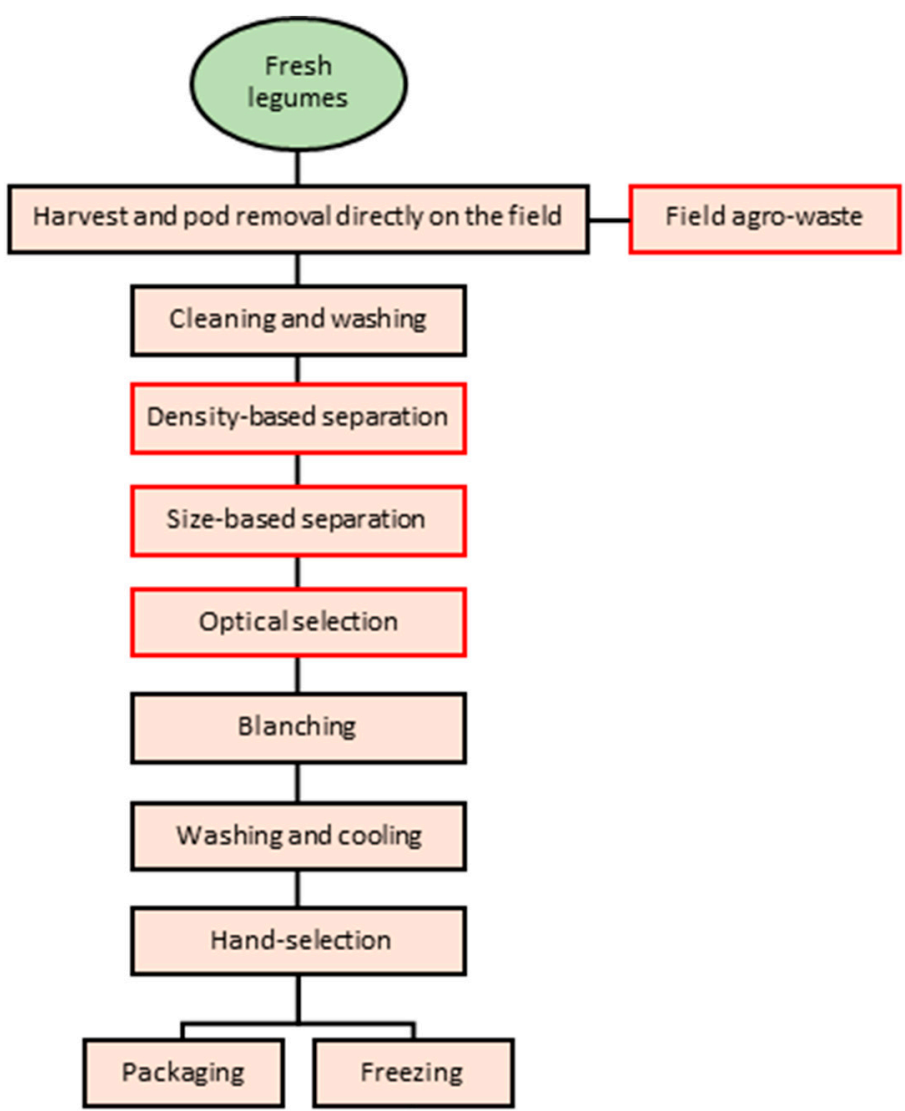

Figure 6. The industrial processing scheme of fresh legumes; in red are the steps generating by-products/wastes. Modified from Andreotti [31].

As shown in the flow chart, after the harvest, the pods are removed directly on the field and shelled generating a large amount of agro-waste consisting of empty pods, leaves and stems. The fresh seeds are delivered to the plant where they enter industrial processing (Figure 6). Generally, considering the transformation processes starting from fresh seeds, by-products are sequentially generated during the initial quality selection steps which start with a density-based separation to select the ripe grains, regardless of the size as legume density usually increases with the degree of maturation [32]. Additional residues are obtained during the size-based separation and the optical selection phases, as well as during the final hand selection before the preserving process [33]. By-products generated during pea industrial processing usually encompass processed and discarded seeds, hulls and dark or spotted seeds (Figure 7).
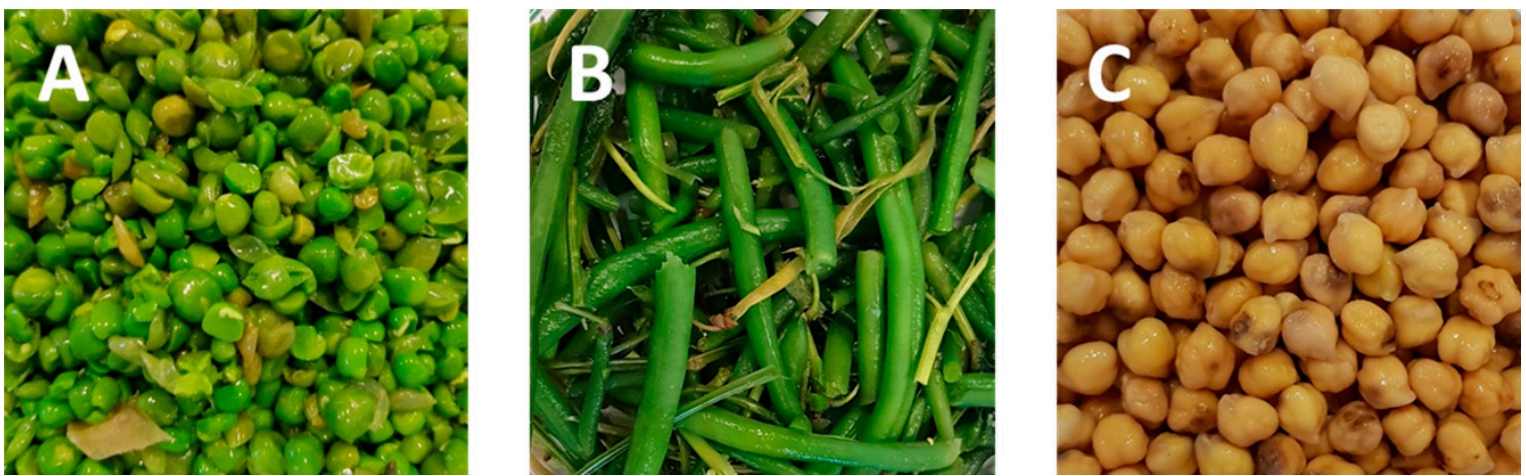

Figure 7. Residues generated during the industrial processing of legumes by Conserve Italia Scarl. (Italy). (A) peas; (B) green beans; (C) chickpeas. Images from Chiara Zurlini. 


\section{Legume Extraction Technologies}

Currently, legume extraction and fractionation technologies have been developed mainly to extract proteins and, to a much lesser extent, other molecules (e.g., fibers or phenols) from legume seeds $[11,34]$. These technologies have been demonstrated to also apply to legume by-products and wastes $[19,35,36]$.

Protein extraction can be carried out either through dry or wet processing. Dry fractionation seems to be the most promising technology for protein extraction from legume seeds and it represents a good alternative to water extraction because it preserves protein functionality [34]. The procedure was initially developed for wheat to separate the husk from the grain and wheat germ from endosperm [34]. It consists of fine milling to detach starch granules and protein bodies, thus allowing subsequent separation based on the size or density of these particles by air classification, also involving electrostatic separation processes. Dry fractionation, for separation of protein-rich and starch-rich fractions, was applied on a commercial scale to pulses (i.e., the dry edible part of legume seeds including yellow peas, chickpeas, lentils, beans) and cereals (in particular wheat) [34,37]. To date, only a few studies demonstrated the valorization of legumes by-products generated after dry milling, such as the recovery of nutrition-valuable protein-rich fractions from moth beans (Vigna aconitifolia) husks [35].

Wet processing technologies generally provide flours with a higher protein purity than dry processing. Among these technologies, alkaline/acid, solvent and enzymatic extractions and the use of ultrafiltration membranes were the most applied processes to legumes seeds and fractions [38-40].

Aqueous alkaline extraction followed by isoelectric precipitation is the most used technique for the extraction of proteins from legume seeds and residues [19].

The process typically involves a milling and/or defatting pre-treatment of the legume feedstocks to remove fiber and fat and decrease the particle size for efficient extraction. Alkaline extraction $(\mathrm{pH}$ 8-11) is conventionally employed to improve protein solubility and is generally followed by filtration to remove insoluble carbohydrate material $[36,41]$. However, the extreme alkaline conditions may alter the functionality and digestibility of the proteins as a result of denaturation, hydrolysis, cross-linking and racemization, as well as the loss of essential amino acids [19].

Legume protein wet extraction can also be obtained with aqueous buffer solutions or under acidic conditions [41]. The solubility of pulse proteins is also high under very low $\mathrm{pH}(\mathrm{pH}<4.0)$; after filtration, the liquid extract is subjected to isoelectric precipitation, cryo-precipitation or membrane filtration to isolate proteins [41,42]. Membrane separation takes advantage of the higher molecular weight of proteins to separate them from other soluble components in the extract. Isolated proteins are then washed and dried to obtain concentrates or isolates, depending on targeted protein purity [41]. This technique is also economically sustainable when applied on a large scale for the production of proteins from different waste sources [43].

Membrane-based ultrafiltration (UF) is another important alternative method for legume protein isolation to traditional isoelectric precipitation $[41,44,45]$. In comparison to the isoelectric approach, this process can be operated under milder conditions and shows a high yield of protein recovery given the efficient membrane retention $[19,41,45]$.

Enzymatic hydrolysis, by using animal or plant-derived proteases under mild conditions ( $\mathrm{pH}$ 6-8), is also an efficient method that, after optimization of the digestion conditions, does not decrease the functionality of extracted proteins [36,46]. Protein enzymatic extraction can also lead to the production of peptide hydrolysates and may be useful in modulating the biological and functional properties of food proteins. Legume proteins, such as soy $[36,47,48]$, peas and several varieties of beans $[49,50]$ have already been subjected to enzymatic hydrolysis. Protein recovery by enzymatic hydrolysis from agro-food residues, among which legumes and more particularly soybean, has also been widely studied by using different plant or animal proteases, also in combination with carbohydrolases, to promote the solubilization of proteins from cell wall components [19,37,51].

Organic solvent (e.g., ethanol) extraction processes have been used on an industrial scale for solid-liquid separation of valuable molecules, such as lipids and proteins, providing final ingredients 
with good nutritional properties [19,36]. However, during the process, the proteins' functional properties might be altered, significantly limiting their applications, as shown for proteins extracted from soybeans hulls [52]. Organic solvents can also be used for the extraction of the bioactive phenolic fraction [53] and this technique can be applied to legume by-products [54].

The above-mentioned protein extraction techniques can be assisted by the application of power ultrasound at a frequency of $20 \mathrm{kHz}$. Ultrasound-assisted extraction (UAE) is an inexpensive and efficient technology to improve the yields achieved using conventional solid-liquid extraction techniques. The main advantages of UAE includes the improved penetration of the solvent into cellular material, enhancement of mass transfer due to the cavitation effect that facilitates the release of extractable compounds [17] and the reduction in the use of hazardous solvents, classifying it as a green technique complying with the standards set by the Environmental Protection Agency (USA) [55].

Recent research revealed that UAE intensifies the extraction of valuable components from soybeans leading to $10 \%$ improved yields of protein, oil and solids [56]. Furthermore, the development of an ultrasound-assisted method to extract natural antioxidants from the mung bean seed coat was reported [57]. Lafarga et al. [58] have used acoustic energy in the acid/alkaline extraction of proteins from Ganxet beans and observed increased yields of solubilized proteins, especially when the extraction was performed at high sodium hydroxide concentrations $(0.3-0.4 \mathrm{M})$. The high yield that can be obtained in UAE processes is of major interest from an industrial point of view, since the technology is an add on step to an existing process, thus needing minimal infrastructural modifications.

Microwave-assisted extraction with electromagnetic waves with frequency ranging from $300 \mathrm{MHz}$ to $300 \mathrm{GHz}$ has also been studied in order to increase bioactive molecules extraction yields. The energy for this range of frequencies directly generates heat within the sample, as a consequence of molecule vibration, and enhances the extraction capacities of other combined methods [59]. Soluble proteins were extracted from soybean seeds by applying a laboratory-scale MW-assisted extraction [60]. However, the application of microwaves to protein extraction from legume by-products and from other sources is only scarcely reported.

\section{Applications of Peas, Beans and Chickpeas By-Products and Wastes}

A summary of the most relevant applications of peas, beans and chickpeas by-products/wastes and/or of their extracts and of the involved bioactive molecules is reported in Table 2.

\subsection{Feed}

In recent years, increasing human consumption of meat has raised market demand for grain legumes for animal feed, resulting in a massive production of residual legume biomass that needs to be further valorized [61].

The increased interest in legume by-product/waste streams lies mainly in the possibility of recovering high-quality proteins, which are characterized by high levels of palatability and digestibility and could be further used as feed for all forms of livestock. This application contributes to the reduction of cereal and soybean levels in livestock diets in intensive production systems. Recently, it was estimated that $10 \%$ to $20 \%$ of livestock diet consists of various legumes, with a maximal inclusion level of up to 50\% (FAOSTAT data, 2017 [25]).

Considerable research on the use of legumes and their by-products as animal feed was carried out by several groups and summarized in the reports published by FAO for the occasion of the International Year of Pulses declared by the United Nations General Assembly in 2016 [62,63]. According to these publications, the potential use of legumes and their by-products as feed is mainly due to two factors: 1 ) the positive contribution of nutrients to the animal diet; 2 ) the low presence of anti-nutritional factors. Legumes and their by-products are in fact important for animal nutrition as they are excellent sources of amino acids, carbohydrates, fibers, minerals, vitamins, phenols and essential fatty acids $[12,20,21]$. In general, legume by-products have higher dry matter digestibility, contain more energy for metabolism and have lower fiber content than cereals. Thus, complementing animal feed with different varieties 
of legume-derived ingredients, significantly improves animal nutrition [63]. However, legumes also contain various anti-nutritional factors (e.g., lectins, agglutinins, saponins, cyanogenic glucosides, alkaloids and biogenic amines) $[64,65]$, which may affect their direct use as animal feed, particularly in monogastric animals (e.g., poultry) [63].

Nevertheless, the effects of these factors disappear or decrease when legumes are properly processed (e.g., by roasting, soaking, cooking, autoclaving, boiling, fermentation and seed de-hulling) [64,65].

Among the different types of legume by-products, in particular empty pea pods and left-overs after pea shelling, were deeply investigated $[66,67]$. These residues are rich in crude proteins (about $20.4 \%$ of dry matter (DM)), fiber (neutral detergent fiber 48.1\% DM; acid detergent fiber $35.4 \% \mathrm{DM}$ ), total soluble carbohydrates (35.6\% DM), total phenolics (9.4\% DM), macrominerals (e.g., $0.85 \% \mathrm{DM}$ of $\mathrm{Ca}, 0.38 \% \mathrm{DM}$ of $\mathrm{Mg}$ ) and microminerals (e.g., $237 \mathrm{ppm}$ of Fe) [66]. Pea pods could serve as a highly palatable source of nutrients for ruminants and could help to decrease the costs in animal farming [66]. 
Table 2. Summary of most relevant applications of peas, beans and chickpeas byproducts/wastes and/or of their derived extracts.

\begin{tabular}{|c|c|c|c|c|c|}
\hline Legume Feedstock & Field of Application & Application & Bioactive Compounds & Outcome & Reference \\
\hline $\begin{array}{l}\text { Pea pods } \\
\text { Pulses by-products }\end{array}$ & Feed & $\begin{array}{l}\text { Monogastric and polygastric } \\
\text { animal feed }\end{array}$ & Proteins, fibers, minerals & $\begin{array}{c}\text { Biochemical and nutritional } \\
\text { characterization. Impact on animal } \\
\text { performance. }\end{array}$ & {$[62,63,66,67]$} \\
\hline Pigeon pea by-products & Food & High protein biscuits & Proteins & $\begin{array}{c}\text { Chemical composition; physical and } \\
\text { sensory parameters }\end{array}$ & [68] \\
\hline Pea and broad bean pods & Food & Food ingredients & $\begin{array}{l}\text { Fibers, soluble sugars, minerals, } \\
\text { linoleic acid }\end{array}$ & $\begin{array}{c}\text { Biochemical and nutritional } \\
\text { characterization; antioxidant activity }\end{array}$ & {$[20,21]$} \\
\hline Pea pod waste & Bio-resources & Bio-butanol production & Cellulose/hemicellulose & $\begin{array}{l}\text { Potential carbon source for bio-butanol } \\
\text { production }\end{array}$ & [69] \\
\hline Moth bean milling residues & Food & Food ingredients & $\begin{array}{l}\text { High essential amino acids, fatty } \\
\text { acids, minerals. }\end{array}$ & $\begin{array}{l}\text { Water and oil absorption capacities, } \\
\text { foaming and emulsification properties. }\end{array}$ & [35] \\
\hline $\begin{array}{l}\text { Black gram (Vigna mungo) milling } \\
\text { by-products }\end{array}$ & Food & Food ingredients & $\begin{array}{l}\text { Phenolic acids like gallic, } \\
\text { protocatechuic, gentisic, vanillic, } \\
\text { syringic, caffeic and ferulic acids }\end{array}$ & $\begin{array}{l}\text { Biochemical and nutritional } \\
\text { characterization; } \alpha \text {-glucosidase inhibitory } \\
\text { activities correlated to potential } \\
\text { antioxidant and anti-diabetic properties. }\end{array}$ & [54] \\
\hline $\begin{array}{l}\text { Red, green and black gram } \\
\text { by-products }\end{array}$ & Food & Deep-fried snacks & Proteins & Sensory results and shelf life studies & [71] \\
\hline Bean pod ash nanoparticles & Automobile application & Composites with bioreinforcements & Nano-fibers, cellulose & $\begin{array}{l}\text { Increased tensile strength and hardness } \\
\text { values, reduced weight and energy impact }\end{array}$ & [72] \\
\hline Process bean waste & Packaging & Ecopaper for food packaging & Fibers, cellulose & $\begin{array}{l}100 \% \text { recyclable packaging paper obtained } \\
\text { by an eco-sustainable process and certified } \\
\text { for application in direct contact with food }\end{array}$ & [73] \\
\hline Bean dregs & Compost & Compost product of high-quality & Cellulose, hemicellulose & $\begin{array}{l}\text { Improved composting conditions and } \\
\text { compost quality }\end{array}$ & [74]. \\
\hline Bean dregs & Bio-resources & Production of reducing sugar & Sugars & $\begin{array}{l}\text { Efficient method for biomass wastes } \\
\text { liquefaction. }\end{array}$ & [75] \\
\hline Chickpea straw & Feed & Alternative forage in ruminant diet & Proteins, fibers & $\begin{array}{l}\text { High nutritional value, dry matter } \\
\text { digestibility, rumen degradability }\end{array}$ & {$[76,77]$} \\
\hline $\begin{array}{l}\text { Chickpea, mung bean, pigeon pea } \\
\text { hulls }\end{array}$ & Food & Meat additives & Phenolics, flavonoids & $\begin{array}{l}\text { Antioxidant, antimicrobial, antinitrosant } \\
\text { activities }\end{array}$ & {$[78,79]$} \\
\hline
\end{tabular}


Table 2. Cont

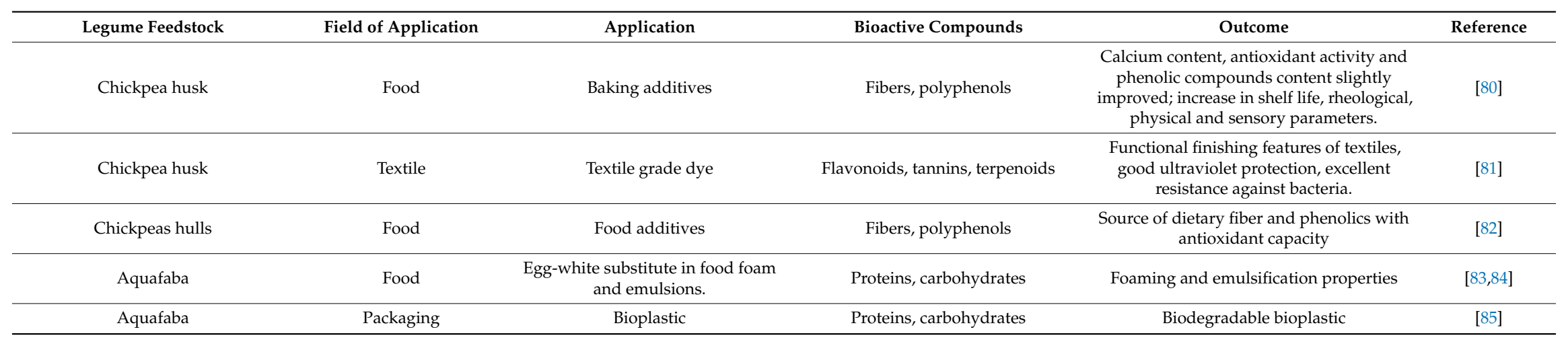


Several by-products of chickpea cultivation and processing are used for animal feeding, including low-grade and culled chickpeas, bran from de-hulling, crop residues (husks, straw) and chickpea hay [76]. In particular, chickpea straw contains higher nutritive value than cereal straws $(44 \%-46 \%$ total digestible nutrients and $4.5 \%-6.5 \%$ protein, $\mathrm{DM}$ basis) and is more palatable than wheat straw. Therefore, it can be used as a ruminant feed [77]. Compared with other straws, chickpea straw has a relatively high nutritive value (e.g., metabolizable energy $=7.7 \mathrm{MJ} / \mathrm{kg} \mathrm{DM}$ for chickpea straw vs. $5.6 \mathrm{MJ} / \mathrm{kg}$ DM for wheat) [77,86], but lower than that of other legume straw such as broad bean (Vicia faba L.), lentil (Lens culinaris Medik) or pea [86].

Dry matter digestibility and rumen degradability of chickpea straw were $10 \%$ to $42 \%$ higher than in cereal straws, indicating that they can be used as an alternative forage in ruminant diets [77]. However, even though its nutritional characteristics are similar to those of other important grain legumes such as pea, chickpea is less used in animal feeding [77].

\subsection{Food}

Nowadays, there has been a growing interest in the food industry towards the potential utilization of legume by-products, mainly related to the presence of high amounts of proteins which could be exploited to create meat analogs for vegetarian/vegan diets, and more generally in the formulation of functional food for human consumption $[87,88]$. Vegetarian and vegan diets have in fact become more and more popular and many consumers see themselves as partial vegetarians and greatly restrict their consumption of animal products. This has led to an increase in the demand for alternative sources of food proteins mainly coming from legumes and their processed products. Proteins enhance the feeling of satiety, can contribute to lowering blood pressure and have a favorable effect on lipid metabolism. For this reason, legume flours and extracts are important sources of plant protein [89]. Legume protein flours, concentrates and isolates can be incorporated into various types of foods (e.g., high protein pasta, crisps, burger patties, nuggets, beverages, baby food, imitation cheese, whipped toppings, soy milk and baked products) to increase their nutritional value and/or to provide specific and desirable functional or technological properties [41,88,90-92]. Flours from different types of legume by-products (Cajanus cajan, Phaseolus aureus Roxb., Phaseolus mungo Roxb.) have been produced and tested to formulate deep-fried snacks, which were evaluated for their physico-chemical, shelf-life and sensory properties [71]. In addition, flours of pigeon pea by-products have been used to produce biscuits with high protein and $10 \%$ lower wheat flower contents [68].

Legume proteins, also extracted from legume residual feedstocks, have been hydrolyzed using economically valuable techniques (e.g., physical, chemical or enzymatic digestion) to produce bioactive peptides [49,51,93]. These peptides showed several potential biological activities, such as angiotensin converting enzyme (ACE)-inhibitory and antioxidant activities [49,93], making them interesting as functional ingredients for food or cosmetic applications.

In recent years, beside vegan and vegetarian products, also the demand of functional food fortified with plant-derived bioactive compounds is progressively increasing. New functional food demand is driven by consumers that are highly aware of the close relationship between nutrition and health and want to include food added with health-promoting ingredients (e.g., fibers and fatty acids) in their diets. Several studies have therefore focused on the development of new ingredients with improved nutritional profiles also recovered from agro-industrial by-products [94]. Among these, legume residues are rich in dietary fibers and, in particular, broad beans and pea pods were studied as a potential nutritionally valuable and significant source of dietary fiber (above $50 \%$ of total weight) for human food consumption $[20,21]$. Chickpea husks have been studied as a source of dietary fibers showing that their addition to baked products, such as white bread, could produce health benefits [80]. Analogously, chickpea hulls also proved to be a good alternative source of dietary fibers and antioxidant phenolics exploitable as ingredients in functional food products. In addition, a wide variety of polyphenols and other molecules (e.g., peptides and lectins) with antioxidant, antimicrobial and other beneficial activities have been extracted from legume residues $[21,53,95]$. These compounds 
have the potential to answer the needs of the food industry by introducing alternative antimicrobial compounds from natural sources and by formulating new green-labeled products. For example, the antibacterial and antifungal properties of chickpeas and peas were studied in relation to their protein and peptide profiles [95].

A great variety of natural sources have been investigated for their antioxidant potential in meat and meat products [96]. Natural antioxidants have a higher consumer acceptance and therefore show a larger range of potential applications in the meat industry, with respect to synthetic molecules [78]. Among many others, also legume phenols, such as some flavonoids showing antioxidant and anti-nitrosant activities coming from chickpea, pigeon pea and mung bean [79], may find an application as additives in meat food products where they take part in the prevention of meat oxidation, which is an important cause for off-flavoring [78]. In addition, peroxidation of meat fats or $\mathrm{N}$ nitrosation, were found among the main causes of statistically significant dose-response relationship between colon-rectal cancer and the consumption of red meat [97]. To this extent, regarding legume extract application, soy protein hydrolysates were added to cooked ground beef with the aim of reducing lipid oxidation [98]. As excess fat may be a pro-cancer factor, fat reduction by replacement with soluble fibers and/or with other protein-rich ingredients (such as chickpea protein-rich flour) seems to be one of the solutions to make healthier processed meats with better nutritional profiles, but without modifying texture and flavor [99].

A particular and interesting legume by-product is aquafaba, the viscous water resulting from chickpea seeds processing, including both the liquid from canned legumes as well as the boiling water from industrial production [83]. It is composed of carbohydrates, proteins, and other soluble plant solids that have migrated from the seeds to the water during the cooking process. The combination of the previous compounds provides this liquid with a wide spectrum of emulsifying, foaming, gelatinizing and thickening properties. Aquafaba is currently used to a limited extent by the food industry, mainly as a substitute for egg white in mayonnaise, dairy products, baked goods (such as meringues and sponge cakes), vegetable snacks, salad dressings and other foods, whereas it has become a popular alternative among vegans $[83,84]$.

\subsection{Cosmetics}

There are many commercial applications of legume extracts for cosmetics but none of them are derived from by-products/wastes. Dried seed legume protein fractions and pea peptide hydrolysates are used as skin moisturizers and soothing/anti-itching actives [100,101]. Legume proteins also showed properties for reducing body perspiration and high fiber pea flour was used as an emulsifier [102]. A commercially available pea extract under the trade name ACTIWHITE PW LS 9860 (by BASF, Germany) is currently used as a skin whitening agent [103].

According to previous reported studies, bioactive protein/peptides, fibers, polyphenols and other molecules could be successfully extracted from legume processing residues $[20,21,67]$ in view of their application as cosmetic ingredients, similarly to phenolic extracts obtained from other types of agro-waste residues [104].

\subsection{Packaging}

Recent trends aim at recovering valuable molecules from legume agro-waste and by-products to be used in the formulation of polymeric materials with new functionalities $[105,106]$. The packaging sector is looking for solutions to modify bio-based and biodegradable polymers in order to meet challenging requirements for food and cosmetics preservation while maintaining their sustainability and biodegradability. One of the main goals is to reduce the consumption of highly expensive bio-based and compostable or biodegradable polymers (such as polyhydroxyalkanoates (PHA), polybutylene succinate (PBS), polycaprolactone (PCL), polylactic acid (PLA)) as well as impart to the biodegradable materials the same properties of the fossil-based ones. In this context, the formulation of materials including residues and/or bioactive molecules extracted from natural wastes/by-products 
was promoted [107]. Technologies and procedures applied to recover proteins and active compounds from legume and other plant feedstocks, also generate a considerable amount of fiber and residual biomass. These can then be valorized for the production of bio-composite materials obtained by mixing a biopolymeric matrix (e.g., PHA, PLA, PBS and PCL) and a defined percentage of reinforcing bio-fillers, such as plant-derived fibers. As natural fibers are renewable, biodegradable, available in large amounts and cheap, they are particularly interesting for the preparation of polymer composites where they can improve the mechanical properties of the matrices and reduce the amount of expensive bio-polymeric matrix present in the final material [108,109]. The residues remaining after protein extraction from legumes have been exploited for the preparation of bio-composites together with polyhydroxyalkanoates (PHAs) as a biodegradable polymeric matrix [110]. This approach enabled the production of rigid packaging items with good mechanical properties and opened perspectives for a packaging market based on new sustainable solutions. In addition, the production of aluminum matrix composites (AMCs) using bean pod ash nanoparticles was studied for automobile application, giving good and promising results [72]. In fact, bean pod ashes can be considered as a promising reinforcement for the production of biocomposites, due to their low density, low cost and availability in large quantities as agricultural wastes.

Aromatic amino acids (such as tryptophan and tyrosine) obtained from the hydrolysis of a protein-rich agricultural waste can also be utilized to impart high UV resistance and UV-shielding features to a polymeric matrix [111]. However, embedding these molecules directly into a polymeric matrix has several drawbacks since they can react with the polymer back-bone giving rise to polymer degradation, or they can leach out of the polymer surface itself. In order to overcome these drawbacks, a protection strategy using hydrotalcite-like compounds (layered double hydroxides, LDH) has been developed [112] to immobilize the amino acids and using them as fillers to impart UV resistance to the polymer matrix [111]. In addition, bio-based polymers and bio-films obtained also from legume seed proteins were produced to be applied as packaging materials and composites. The most studied of these polymers is sourced from the soybean, but films derived from pea proteins showed interesting UV light transmission resistance due to the presence of aromatic amino acids [113]. Given the presence of high amino acid levels in extracted legume agro-waste, it is therefore possible to hypothesize a possible extension of aforementioned applications to protein extracts coming from legume processing residues.

Furthermore, an interesting and recent application in the packaging field is the development of a new type of bioplastic based on chickpea aquafaba [85] that shows great potential for mechanical manufacturing and thus industrial production being completely biodegradable and also vegan-friendly.

Finally, a 100\% recyclable packaging paper was obtained from bean processing waste by an eco-sustainable process and certified for application in direct contact with food [73].

This type of paper was estimated to reduce the use of virgin cellulose from trees by $15 \%$ and the emission of greenhouse gases by $20 \%$.

\subsection{Other Uses}

Recently, chickpea husk was used to extract textile grade dye that is able to impart color to cotton, silk and wool fabrics as well as to give functional finishing features of textiles by using a totally eco-friendly process [81]. Treated fabrics showed a good dye uptake and adequate wash, light and rubbing fastness properties, in addition to a good ultraviolet protection property and excellent resistance against Staphylococcus aureus and Escherichia coli bacteria.

Legume waste was also used in the composting field. Bean dregs (at $0 \%, 35 \%$ and $45 \%$ ) were evaluated as additives during the two-stage composting of green waste, improving process conditions and compost quality [74].

Other applications are reported in Table 2. 


\section{Conclusions}

Legume residues, such as pea, bean and chickpea by-products/wastes, have a high and proven potential in boosting new and diversified market opportunities in several industrial sectors. In particular, the feed and food industries could find in legume residues a valuable source of bioactive and highly nutritional ingredients (e.g., proteins and fibers) that may be obtained by means of green extraction processes from sustainable natural resources. Moreover, the emerging packaging sector is steadily seeking vegetal feedstocks to produce new bio-based materials with improved technical and mechanical features for a wide array of applications, aiming at a progressive reduction of the use of petrol-based polymers and of the cost of the final materials.

The efficient utilisation of the all agro-industrial residues can, therefore, help in reducing the overall economic and environmental impact of the agro-industrial and food processing pipelines. The residues extraction and following exploitation must, therefore, be carried out with low environmental impact and green technologies, which will lead to achieving, hopefully in the near future, a zero-waste economy and a more sustainable bio-based and circular society.

Author Contributions: Writing_original draft preparation, all authors; writing—review and editing, A.T., T.T., C.Z., I.M.C. and P.F.X.C.; funding acquisition, all authors. All authors have read and agreed to the published version of the manuscript.

Funding: This work was supported by the PROLIFIC ("Integrated cascades of PROcesses for the extraction and valorization of protein and bioactive molecules from Legumes, Fungi and Coffee agro-industrial side streams") project, funded by the Bio Based Industries Joint Undertaking, European Union's Horizon 2020 research and innovation program, under grant agreement No 790157.

Acknowledgments: We wish to thank Andrew Brown (Fachhochschule Nordwestschweiz, Switzerland) for critically reviewing the manuscript and editing the English language.

Conflicts of Interest: The authors declare no conflict of interest.

\section{References}

1. Helkar, P.B.; Sahoo, A.K.; Patil, N.J. Review: Food industry by-products used as a functional food ingredients. Int. J. Waste Resour. 2016, 6, 248.

2. Nora, S.M.S.; Ashutosh, S.; Vijaya, R. Potential utilization of fruit and vegetable wastes for food through drying or extraction techniques. Nov. Tech. Nutr. Food Sci. 2017, 1, NTNF.000506.

3. Vis, M.; van den Berg, D. Harmonisation of Biomass Resource Assessments, Volume 1, Best Practices and Methods Handbook, public Deliverable n. 5.3 of the FP7 project BEE Biomass Energy Europe. 2010. [CrossRef]

4. Camia, A.; Robert, N.; Jonsson, R.; Pilli, R.; García-Condado, S.; López-Lozano, R.; van der Velde, M.; Ronzon, T.; Gurría, P.; M’Barek, R.; et al. Biomass production, supply, uses and flows in the European Union. JRC Sci. Policy Rep. 2018. Available online: https://ec.europa.eu/jrc/en/publication/eur-scientific-and-technical-research-reports/ biomass-production-supply-uses-and-flows-european-union-first-results-integrated-assessment (accessed on 10 January 2020).

5. Ronzon, T.; Piotrowski, S. Are primary agricultural residues promising feedstock for the European bioeconomy? Ind. Biotech. 2017, 13, 113-127. [CrossRef]

6. Kaltschmitt, M.; Hartmann, H.; Hofbauer, H. Energie aus Biomasse: Grundlagen, Techniken und Verfahren, 2nd ed.; Springer: Heidelberg, Germany, 2009.

7. European Commission. European Commission Decision of 18 December 2014 Amending Decision 2000/532/EC on the list of Waste Pursuant to Directive 2008/98/EC of the European Parliament and of the Council Text with EEA Relevance. 2014. Available online: http://eur-lex.europa.eu/legal-content/EN/TXT/?uri=uriserv: OJ.L_.2014.370.01.0044.01.ENG (accessed on 9 December 2019).

8. Sárvári Horváth, I.; Tabatabaei, M.; Karimi, K.; Kumar, R. Recent updates on biogas production-a review. Biofuel. Res. J. 2016, 10, 394-402. [CrossRef]

9. Martínez, E.J.; Raghavan, V.; González-Andrés, F.; Gómez, X. New biofuel alternatives: integrating waste management and single cell oil production. Int. J. Mol. Sci. 2015, 16, 9385-9405. [CrossRef] 
10. Lin, C.S.K.; Koutinas, A.A.; Stamatelatou, K.; Mubofu, E.B.; Matharu, A.S.; Kopsahelis, N.; Pfaltzgraff, L.A.; Clark, J.H.; Papanikolaou, S.; Kwan, T.H.; et al. Current and future trends in food waste valorization for the production of chemicals, materials and fuels: A global perspective. Biofuel Bioprod. Bior. 2014, 8, 686-715.

11. Voisin, A.-S.; Guéguen, J.; Huyghe, C.; Jeuffroy, M.-H.; Magrini, M.-B.; Meynard, J.-M.; Mougel, C.; Pellerin, S.; Pelzer, E. Legumes for feed, food, biomaterials and bioenergy in Europe: A review. Agron. Sustain. Dev. 2014, 34, 361-380.

12. Maity, S.K. Opportunities, recent trends and challenges of integrated biorefinery: Part II. Renew. Sustain. Energy Rev. 2015, 43, 1446-1466. [CrossRef]

13. RedCorn, R.; Fatemi, S.; Engelberth, A.S. Comparing end-use potential for industrial food-waste sources. Eng. Prc. 2018, 4, 371-380. [CrossRef]

14. Jin, Q.; Yang, L.C.; Poe, N.; Huang, H.B. Integrated processing of plant-derived waste to produce value-added products based on the biorefinery concept. Trends Food Sci. Tech. 2018, 74, 119-131. [CrossRef]

15. Sadh, P.K.; Duhan, S.; Duhan, J.S. Agro-industrial wastes and their utilization using solid state fermentation: a review. Bioresour. Bioprocess 2018, 5. [CrossRef]

16. Cecilia, J.A.; García-Sancho, C.; Maireles-Torres, P.J.; Luque, R. Industrial food waste valorization: a general overview. In Biorefinery, Integrated Sustainable Processes for Biomass Conversion to Biomaterials, Biofuels, and Fertilizers; Bastidas-Oyanedel, J., Schmidt, J., Eds.; Springer Nature: Cham, Switzerland, 2019; pp. 253-277.

17. Galanakis, C.M. Recovery of high added-value components from food wastes: conventional, emerging technologies and commercialized applications. Trends Food Sci. Technol. 2012, 26, 68-87. [CrossRef]

18. Galanakis, C.M. Separation of functional macromolecules and micromolecules: From ultrafiltration to the border of nanofiltration. Trends Food Sci. Tech. 2015, 42, 44-63. [CrossRef]

19. del Mar Contreras, M.; Lama-Munoz, A.; Gutierrez-Perez, J.M.; Espinola, F.; Moya, M.; Castro, E. Protein extraction from agri-food residues for integration in biorefinery: potential techniques and current status. Bioresour. Technol. 2019, 280, 459-477. [CrossRef] [PubMed]

20. Mateos-Aparicio, I.; Redondo-Cuenca, A.; Villanueva-Suarez, M.J. Broad bean and pea by-products as sources of fibre-rich ingredients: potential antioxidant activity measured in vitro. J. Sci. Food Agric. 2012, 92, 697-703. [CrossRef] [PubMed]

21. Mateos-Aparicio, I.; Redondo-Cuenca, A.; Villanueva-Suarez, M.J.; Zapata-Revilla, M.A.; Tenorio-Sanz, M.D. Pea pod, broad bean pod and okara, potential sources of functional compounds. Lwt-Food Sci. Technol. 2010, 43, 1467-1470. [CrossRef]

22. Mateos-Aparicio, I.; Redondo-Cuenca, A.; Villanueva-Suarez, M.J. Isolation and characterisation of cell wall polysaccharides from legume by-products: Okara (soymilk residue), pea pod and broad bean pod. Food Chem. 2010, 122, 339-345. [CrossRef]

23. Zander, P.; Amjath-Babu, T.S.; Preissel, S.; Reckling, M.; Bues, A.; Schlafke, N.; Kuhlman, T.; Bachinger, J.; Uthes, S.; Stoddard, F.; et al. Grain legume decline and potential recovery in European agriculture: A review. Agron. Sustain. Dev. 2016, 36, 26. [CrossRef]

24. Sirtori, C.R.; Galli, C.; Anderson, J.W.; Arnoldi, A. Nutritional and nutraceutical approaches to dyslipidemia and atherosclerosis prevention: Focus on dietary proteins. Atherosclerosis 2009, 203, 8-17. [CrossRef]

25. FAOSTAT. Food and Agriculture data. 2017. Available online: http://www.fao.org/faostat/en/\#home (accessed on 8 January 2020).

26. Klupšaitè, D.; Juodeikienè, G. Legume: Composition, protein extraction and functional properties. A review. Chem. Technol. 2015, 66. [CrossRef]

27. Chickpea Production Guide. 2004. Available online: https://catalog.extension.oregonstate.edu/sites/catalog/ files/project/pdf/em8791.pdf (accessed on 8 January 2020).

28. Merga, B.; Haji, J. Economic importance of chickpea: production, value, and world trade. Cogent. Food Agric. 2019, 5, 1615718. [CrossRef]

29. Westhoek, H.; Rood, T.; van den Berg, M.; Janse, J.; Nijdam, D.; Reudink, M.; Stehfest, E. The Protein Puzzle. The Consumption and Production of Meat, Dairy and Fish in the European Union; PBL Netherlands Environmental Assessment Agency: The Hague, The Netherlands, 2011.

30. Report EIP-AGRI Focus Group on protein crops. 2014. Available online: https://ec.europa.eu/eip/agriculture/ en/publications/eip-agri-focus-group-protein-crops-final-report (accessed on 8 January 2020).

31. Andreotti, R. La Fabbricazione Delle Conserve di Piselli; Stazione Sperimentale per l'Industria delle Conserve Alimentari: Parma, Italy, 1983. 
32. Tiwari, B.K.; Gowen, A.; McKenna, B. Pulse Foods. Processing, Quality and Nutraceutical Applications; Academic Press: Cambridge, MA, USA; Elsevier: London, UK, 2011.

33. Annor, G.A.; Zhen, M.; Boye, J.I. Crops - Legumes. In Food Processing. Principles and Applications, 2nd ed.; Clark, S., Jung, S., Lamsal, B., Eds.; John Wiley \& Sons, Ltd.: Hoboken, NJ, USA, 2014; pp. 305-337.

34. Schutyser, M.; van der Goot, A.J. The potential of dry fractionation processes for sustainable plant protein production. Trends Food Sci. Tech. 2011, 22, 154-164. [CrossRef]

35. Kamani, M.H.; Martin, A.; Meera, M.S. Valorization of by-products derived from milled moth bean: evaluation of chemical composition, nutritional profile and functional characteristics. Waste Biomass Valor. 2019. [CrossRef]

36. Gençdă̆, E.; Görgüç, A.; Yılmaz, F. Recent advances in the recovery techniques of plant-based proteins from agro-industrial by-products. Food Rev. Int. 2020. [CrossRef]

37. Pelgrom, P.J.M.; Vissers, A.M.; Boom, R.M.; Schutyser, M.A.I. Dry fractionation for production of functional pea protein concentrates. Food Res. Int. 2013, 53, 232-239. [CrossRef]

38. Brummer, Y.; Kaviani, M.; Tosh, S.M. Structural and functional characteristics of dietary fibre in beans, lentils, peas and chickpeas. Food Res. Int. 2015, 67, 117-125. [CrossRef]

39. Roy, F.; Boye, J.I.; Simpson, B.K. Bioactive proteins and peptides in pulse crops: Pea, chickpea and lentil. Food Res. Int. 2010, 43, 432-442. [CrossRef]

40. Tosh, S.M.; Yada, S. Dietary fibres in pulse seeds and fractions: Characterization, functional attributes, and applications. Food Res. Int. 2010, 43, 450-460. [CrossRef]

41. Boye, J.; Zare, F.; Pletch, A. Pulse proteins: Processing, characterization, functional properties and applications in food and feed. Food Res. Int. 2010, 43, 414-431. [CrossRef]

42. Makri, E.; Papalamprou, E.; Doxastakis, G. Study of functional properties of seed storage proteins from indigenous European legume crops (lupin, pea, broad bean) in admixture with polysaccharides. Food Hydrocoll. 2005, 19, 583-594. [CrossRef]

43. Gong, A.; Aguirre, A.M.; Bassi, A. Technical issues related to characterization, extraction, recovery, and purification of proteins from different waste sources. In Protein Byproducts; Dhillon, G., Ed.; Academic Press; Elsevier: Cambridge, MA, USA, 2016; pp. 89-106.

44. Des Marchais, L.-P.; Foisy, M.; Mercier, S.; Villeneuve, S.; Mondor, M. Bread-making potential of pea protein isolate produced by a novel ultrafiltration/diafiltration process. Procedia Food Sci. 2011, 1, 1425-1430. [CrossRef]

45. Mondor, M.; Aksay, S.; Drolet, H.; Roufik, S.; Farnworth, E.; Boye, J.I. Influence of processing on composition and antinutritional factors of chickpea protein concentrates produced by isoelectric precipitation and ultrafiltration. Innov. Food Sci. Emerg. Technol. 2009, 10, 342-347. [CrossRef]

46. Sarethy, I.P. Plant peptides: bioactivity, opportunities and challenges. Protein Pept. Lett. 2017, 24, 102-108. [CrossRef] [PubMed]

47. Ribotta, P.D.; Rosell, C.M. Effects of enzymatic modification of soybean protein on the pasting and rheological profile of starch-protein systems. Starch 2010, 62, 373-383. [CrossRef]

48. Barac, M.B.; Jovanovic, S.T.; Stanojevic, S.P.; Pesic, M.B. Effect of limited hydrolysis on traditional soy protein concentrate. Sensors 2006, 6, 1087-1101. [CrossRef]

49. Pownall, T.L.; Udenigwe, C.C.; Aluko, R.E. Amino acid composition and antioxidant properties of pea seed (Pisum sativum L.) enzymatic protein hydrolysate fractions. J. Agric. Food Chem. 2010, 58, 4712-4718. [CrossRef]

50. Aluko, R.E. Determination of nutritional and bioactive properties of peptides in enzymatic pea, chickpea, and mung bean protein hydrolysates. AOAC Int. 2008, 91, 947-956. [CrossRef]

51. Rojas, M.J.; Siqueira, P.F.; Miranda, L.C.; Tardioli, P.W.; Giordano, R.L.C. Sequential proteolysis and cellulolytic hydrolysis of soybean hulls for oligopeptides and ethanol production. Ind. Crop. Prod. 2014, 61, 202-210. [CrossRef]

52. Sawada, M.M.; Venancio, L.L.; Toda, T.A.; Rodrigues, C.E.C. Effects of different alcoholic extraction conditions on soybean oil yield, fatty acid composition and protein solubility of defatted meal. Food Res. Int. 2014, 62, 662-670. [CrossRef]

53. Xu, B.J.; Chang, S.K.C. A comparative study on phenolic profiles and antioxidant activities of legumes as affected by extraction solvents. J. Food Sci. 2007, 72, S159-S166. [CrossRef] [PubMed] 
54. Girish, T.K.; Pratape, V.M.; Rao, U.J.S.P. Nutrient distribution, phenolic acid composition, antioxidant and alpha-glucosidase inhibitory potentials of black gram (Vigna mungo L.) and its milled by-products. Food Res. Int. 2012, 46, 370-377. [CrossRef]

55. Azmir, J.; Zaidul, I.S.M.; Rahman, M.M.; Sharif, K.M.; Mohamed, A.; Sahena, F.; Jahurul, M.H.A.; Ghafoor, K.; Norulaini, N.A.N.; Omar, A.K.M. Techniques for extraction of bioactive compounds from plant materials: A review. J. Food Eng. 2013, 117, 426-436. [CrossRef]

56. Preecea, K.E.; Hooshyar, N.; Krijgsman, A.; Fryer, P.J.; Zuidam, N.J. Intensified soy protein extraction by ultrasound. Chem. Eng. Process. 2017, 113, 94-101. [CrossRef]

57. Zhou, Y.; Zheng, J.; Gan, R.Y.; Zhou, T.; Xu, D.P.; Li, H.B. Optimization of ultrasound-assisted extraction of antioxidants from the mung bean coat. Molecules 2017, 22, 638. [CrossRef]

58. Lafarga, T.; Alvarez, C.; Bobo, G.; Aguilo-Aguayo, I. Characterization of functional properties of proteins from Ganxet beans (Phaseolus vulgaris L. var. Ganxet) isolated using an ultrasound-assisted methodology. Lwt-Food Sci. Technol. 2018, 98, 106-112. [CrossRef]

59. Ochoa-Rivas, A.; Nava-Valdez, Y.; Serna-Saldivar, S.O.; Chuck-Hernandez, C. Microwave and ultrasound to enhance protein extraction from peanut flour under alkaline conditions: effects in yield and functional properties of protein isolates. Food Bioprocess Tech. 2017, 10, 543-555. [CrossRef]

60. Choi, I.; Choi, S.J.; Chun, J.K.; Moon, T.W. Extraction yield of soluble protein and microstructure of soybean affected by microwave heating. J. Food. Process. Pres. 2006, 30, 407-419. [CrossRef]

61. de Boer, J.; Helms, M.; Aiking, H. Protein consumption and sustainability: Diet diversity in EU-15. Ecol. Econ. 2006, 59, 267-274. [CrossRef]

62. The International Year of Pulses-Final Report; FAO: Rome, Italy, 2019. Available online: http://www.fao.org/3/ CA2853EN/ca2853en.pdf (accessed on 20 December 2019).

63. Sharasia, P.L.; Garg, M.R.; Bhanderi, B.M. Pulses and Their by-Products as Animal Feed; FAO: Rome, Italy, 2017. Available online: http://www.fao.org/3/a-i7779e.pdf (accessed on 20 December 2019).

64. Soetan, K.O.; Oyewole, O.E. The need for adequate processing to reduce the antinutritional factors in plants used as human foods and animal feeds: a review. Afr. J. Food Sci. 2009, 3, 223-232.

65. Naila, A.; Flint, S.; Fletcher, G.; Bremer, P.; Meerdink, G. Control of biogenic amines in food-existing and emerging approaches. J. Food Sci. 2010, 75, R139-R150. [CrossRef] [PubMed]

66. Wadhwa, M.; Kaushal, S.; Bakshi, M.P.S. Nutritive evaluation of vegetable wastes as complete feed for goat bucks. Small Ruminant Res. 2006, 64, 279-284. [CrossRef]

67. Dhillon, G.S. Protein Byproducts-Transformation from Environmental Burden Into Value-Added Products; Academic Press: London, UK, 2016.

68. Tiwari, B.K.; Brennan, C.S.; Jaganmohan, R.; Surabi, A.; Alagusundaram, K. Utilisation of pigeon pea (Cajanus cajan L) byproducts in biscuit manufacture. Lwt-Food Sci. Technol. 2011, 44, 1533-1537. [CrossRef]

69. Nimbalkar, P.R.; Khedkar, M.A.; Chavan, P.V.; Bankar, S.B. Biobutanol production using pea pod waste as substrate: Impact of drying on saccharification and fermentation. Renew. Energy 2018, 117, 520-529. [CrossRef]

70. Verma, N.; Bansal, M.C.; Kumar, V. Pea peel waste: A lignocellulosic waste and its utility in cellulase production by Trichoderma reesei under solid state cultivation. Bioresources 2011, 6, 1505-1519.

71. Tiwari, U.; Gunasekaran, M.; Jaganmohan, R.; Alagusundaram, K.; Tiwari, B.K. Quality characteristic and shelf life studies of deep-fried snack prepared from rice brokens and legumes by-product. Food Bioprocess. Tech. 2011, 4, 1172-1178. [CrossRef]

72. Aigbodion, V.S. Bean pod ash nanoparticles a promising reinforcement for aluminium matrix biocomposites. J. Mater. Res. Technol. 2019, 8, 6011-6020. [CrossRef]

73. ANSA. Arriva Carta Eco-Sostenibile da Scarti di Fagioli. Available online: http://www.ansa.it/canale_ ambiente/notizie/rifiuti_e_riciclo/2015/09/18/arriva-carta-eco-sostenibile-da-scarti-di-fagioli_1ed8193173db-11e5-9836-00505695d1bc.html (accessed on 31 January 2020).

74. Zhang, L.; Sun, X.Y. Effects of bean dregs and crab shell powder additives on the composting of green waste. Bioresour. Technol. 2018, 260, 283-293. [CrossRef]

75. Zhu, G.Y.; Zhu, X.; Fan, Q.; Wan, X.L. Production of reducing sugars from bean dregs waste by hydrolysis in subcritical water. J. Anal. Appl. Pyrol. 2011, 90, 182-186. [CrossRef]

76. Taylor, W.J.; Ford, R. Chickpea. In Pulses, Sugar and Tuber Crops; Springer-Verlag: Berlin/Heidelberg, Germany, 2007; pp. 109-122. 
77. Bampidis, V.A.; Christodoulou, V. Chickpeas (Cicer arietinum L.) in animal nutrition: A review. Anim. Feed Sci. Tech. 2011, 168, 1-20. [CrossRef]

78. Kumar, Y.; Yadav, D.N.; Ahmad, T.; Narsaiah, K. Recent Trends in the Use of Natural Antioxidants for Meat and Meat Products. Compr. Rev. Food Sci. Food Saf. 2015, 14, 796-812. [CrossRef]

79. Kanatt, S.R.; Arjun, K.; Sharma, A. Antioxidant and antimicrobial activity of legume hulls. Food Res. Int. 2011, 44, 3182-3187. [CrossRef]

80. Niño-Medina, G.; Muy-Rangel, D.; de la Garza, A.L.; Rubio-Carrasco, W.; Perez-Meza, B.; Araujo-Chapa, A.P.; Gutierrez-Alvarez, K.A.; Urias-Orona, V. Dietary fiber from chickpea (Cicer arietinum) and soybean (Glycine max) husk byproducts as baking additives: functional and nutritional properties. Molecules 2019, 24, 991. [CrossRef] [PubMed]

81. Jose, S.; Pandit, P.; Pandey, R. Chickpea husk-A potential agro waste for coloration and functional finishing of textiles. Ind. Crop. Prod. 2019, 142, 111833. [CrossRef]

82. Niño-Medina, G.; Muy-Rangel, D.; Urías-Orona, V. Chickpea (Cicer arietinum) and soybean (Glycine max) hulls: byproducts with potential use as a source of high value-added food products. Waste Biomass. Valor. 2017, 8, 1199-1203. [CrossRef]

83. Buhl, T.F.; Christensen, C.H.; Hammershoj, M. Aquafaba as an egg white substitute in food foams and emulsions: protein composition and functional behavior. Food Hydrocoll. 2019, 96, 354-364. [CrossRef]

84. Mustafa, R.; He, Y.; Shim, Y.Y.; Reaney, M.J.T. Aquafaba, wastewater from chickpea canning, functions as an egg replacer in sponge cake. Int. J. Food. Sci. Tech. 2018, 53, 2247-2255. [CrossRef]

85. Material District. Bioplastic made from Aquafaba from Chickpeas. 2019. Available online: https://materialdistrict. com/article/bioplastic-aquafaba-chickpeas/ (accessed on 31 January 2020).

86. López, S.; Davies, D.R.; Giraldez, F.J.; Dhanoa, M.S.; Dijkstra, J.; France, J. Assessment of nutritive value of cereal and legume straws based on chemical composition and in vitro digestibility. J. Sci. Food Agric. 2005, 85, 1550-1557. [CrossRef]

87. Kumar, P.; Chatli, M.K.; Mehta, N.; Singh, P.; Malav, O.P.; Verma, A.K. Meat analogues: health promising sustainable meat substitutes. Crit. Rev. Food Sci. Nutr. 2017, 57, 923-932. [CrossRef]

88. Singhal, A.; Karaca, A.C.; Tyler, R.; Nickerson, M. Pulse proteins: from processing to structure-function relationships. In Grain Legumes; Goyal, A., Ed.; IntechOpen Limited: London, UK, 2016.

89. Jahreis, G.; Brese, M.; Leiterer, M.; Schafer, U.; Bohm, V. Legume flours: nutritionally important sources of protein and dietary fiber. Ernahrungs Umschau 2016, 63, M82-M88.

90. Raikos, V.; Neacsu, M.; Russell, W.; Duthie, G. Comparative study of the functional properties of lupin, green pea, fava bean, hemp, and buckwheat flours as affected by pH. Food Sci. Nutr. 2014, 2, 802-810. [CrossRef] [PubMed]

91. Burger, T.G.; Zhang, Y. Recent progress in the utilization of pea protein as an emulsifier for food applications. Trends Food Sci. Tech. 2019, 86, 25-33. [CrossRef]

92. Liu, F.; Chen, Z.; Tang, C.H. Microencapsulation properties of protein isolates from three selected Phaseolus legumes in comparison with soy protein isolate. Lwt-Food Sci. Technol. 2014, 55, 74-82. [CrossRef]

93. Boschin, G.; Scigliuolo, G.M.; Resta, D.; Arnoldi, A. ACE-inhibitory activity of enzymatic protein hydrolysates from lupin and other legumes. Food Chem. 2014, 145, 34-40. [CrossRef] [PubMed]

94. Oreopoulou, V.; Tzia, C. Utilization of plant by-products for the recovery of proteins, dietary fibers, antioxidants, and colorants. In Utilization of By-Products and Treatment of Waste in the Food Industry; Oreopoulou, V., Russ, W., Eds.; Springer: Boston, MA, USA, 2007; pp. 209-232.

95. Pina-Pérez, M.C.; Ferrús Pérez, M.A. Antimicrobial potential of legume extracts against foodborne pathogens: a review. Trends Food Sci. Tech. 2018, 72, 114-124. [CrossRef]

96. Ribeiro, J.S.; Santos, M.J.M.C.; Silva, L.K.R.; Pereira, L.C.L.; Santo, I.A.; Lannes, S.C.D.; da Silva, M.V. Natural antioxidants used in meat products: A brief review. Meat Sci. 2019, 148, 181-188. [CrossRef]

97. Bouvard, V.; Loomis, D.; Guyton, K.Z.; Grosse, Y.; Ghissassi, F.E.; Benbrahim-Tallaa, L.; Guha, N.; Mattock, H.; Straif, K. International Agency for Research on Cancer Monograph Working, G., Carcinogenicity of consumption of red and processed Meat. Lancet Oncol. 2015, 16, 1599-1600. [CrossRef]

98. Zhang, L.; Li, J.R.; Zhou, K.Q. Chelating and radical scavenging activities of soy protein hydrolysates prepared from microbial proteases and their effect on meat lipid peroxidation. Bioresour. Technol. 2010, 101, 2084-2089. [CrossRef] 
99. Brewer, M.S. Reducing the fat content in ground beef without sacrificing quality: A review. Meat Sci. 2012, 91, 385-395. [CrossRef]

100. Voegeli, R.; Stocker, K.; Mueller, C. Protein fraction for cosmetic and dermatology care of the skin. US Patent US 94384892 A, 21 June 1994

101. Dal Farra, C.; Domloge, N.; Botto, J.M. Use of A Peptide Hydrolysate of pea as Moisturizing Active Agent. US Patent US201113640827 A, 1 December 2015.

102. Banowski, B.; Evers, S. Antiperspirant Cosmetics Comprising Specific Proteins from Legumes of the Genus Pisum and/or Phaseolus and/or Vigna and/or Macrotyloma or from Cruciferous Plants of the Genus Brassica and Including no Aluminum and/or Zirconium Halides and/or Hydroxy Halides. US Patent US 201715400773 A, 13 November 2018.

103. Moussou, P.; Danoux, L.; Bailly, L.; Gillon, V. Cosmetic Composition Comprising a Combination of a Sugar Fatty Acid Ester with a Plant Extract of Waltheria indica or Pisum sativum for Skin Whitening. US Patent US 29420307 A, 24 April 2018.

104. Galanakis, C.M.; Tsatalas, P.; Galanakis, I.M. Implementation of phenols recovered from olive mill wastewater as UV booster in cosmetics. Ind. Crops Prod. 2018, 111, 30-37. [CrossRef]

105. Kumar, V.; Longhurst, P. Recycling of food waste into chemical building blocks. Curr. Opin. Green. Sustain. Chem. 2018, 13, 118-122. [CrossRef]

106. Tuck, C.O.; Perez, E.; Horvath, I.T.; Sheldon, R.A.; Poliakoff, M. Valorization of biomass: Deriving more value from waste. Science 2012, 337, 695-699. [CrossRef] [PubMed]

107. European Commission. Packaging-Requirements for Packaging Recoverable through Composting and Biodegradation-Test Scheme and Evaluation Criteria for the Final Acceptance of Packaging, CEN EN 13432:2000. 2000. Available online: http://ec.europa.eu/environment/waste/packaging/standards.htm (accessed on 9 December 2019).

108. Totaro, G.; Sisti, L.; Vannini, M.; Marchese, P.; Tassoni, A.; Lenucci, M.S.; Lamborghini, M.; Kalia, S.; Celli, A. A new route of valorization of rice endosperm by-product: production of polymeric biocomposites. Compos. Part B-Eng. 2018, 139, 195-202. [CrossRef]

109. Saccani, A.; Sisti, L.; Manzi, S.; Fiorini, M. PLA composites formulated recycling residues of the winery industry. Polym. Compos. 2019, 40, 1378-1383. [CrossRef]

110. Cinelli, P.; Mallegni, N.; Gigante, V.; Montanari, A.; Seggiani, M.; Coltelli, M.B.; Bronco, S.; Lazzeri, A. Biocomposites based on polyhydroxyalkanoates and natural fibres from renewable by-products. Appl. Food Biotech. 2019, 6, 35-42.

111. Marek, A.A.; Verney, V.; Taviot-Gueho, C.; Totaro, G.; Sisti, L.; Celli, A.; Leroux, L. Oustanding chain-extension effect and high UV resistance of polybutylene succinate containing amino-acid-modified layered double hydroxides. Beilstein J. Nanotechnol. 2019, 10, 684-695. [CrossRef]

112. Totaro, G.; Sisti, L.; Celli, A.; Aloisio, I.; Di Gioia, D.; Marek, A.A.; Verney, V.; Leroux, F. Dual chain extension effect and antibacterial properties of biomolecules interleaved within LDH dispersed into PBS by in situ polymerization. Dalton Trans. 2018, 47, 3155-3165. [CrossRef]

113. Shi, W.; Dumont, M.J. Review: bio-based films from zein, keratin, pea, and rapeseed protein feedstocks. J. Mater. Sci. 2014, 49, 1915-1930. [CrossRef]

(C) 2020 by the authors. Licensee MDPI, Basel, Switzerland. This article is an open access article distributed under the terms and conditions of the Creative Commons Attribution (CC BY) license (http://creativecommons.org/licenses/by/4.0/). 